\title{
The frequency and meiotic behaviour of structural chromosome variants in natural populations of Allium schoenoprasum L. (wild chives) in Europe
}

\author{
J. P. STEVENS* \& S. M. BOUGOURD† \\ Department of Biology, University of York, York YO1 5DD, UK.
}

\begin{abstract}
Meiotic analysis of 1017 plants of Allium schoenoprasum, sampled as adults from 18 natural populations in Britain and continental Europe, revealed that 35 (3.4 per cent) were heterozygous for one or more major structural chromosome mutations. Nineteen different interchanges, 11 different inversions, one deletion, and one supernumerary chromosome segment were found. There was no significant difference between British and continental European populations in the frequency of chromosomal variants.

There was considerable variation in meiotic behaviour between different interchanges. On average, quadrivalent formation occurred in 68 per cent meiocytes, but the range (from 13 to 95 per cent) was wide. In five interchange heterozygotes, chiasma formation in the interstitial segments occurred in a high proportion of multivalents. In three interchange heterozygotes, a significant excess of chain quadrivalents were in alternate orientation. In the inversion heterozygotes, the frequency of reverse loop chiasma formation was relatively low, occurring, on average, in 6 per cent meiocytes (with a range from 3 to 13 per cent). The pollen and ovule fertilities of inversion heterozygotes were little affected, but those of many interchange heterozygotes were significantly depressed.

The distribution of structural chromosome mutations throughout the genome was not random. A disproportionately high frequency involved the acrocentric, nucleolar-organizer chromosome pair.
\end{abstract}

Keywords: Allium schoenoprasam, chromosome variants, non-random chromosome rearrangements, meiotic analysis, population cytogenetics.

\section{Introduction}

Structural chromosome rearrangements have considerable potential for modifying patterns of genetic recombination at meiosis, thereby conserving or creating specific gene combinations. When structural chromosome mutants occur at a low frequency in natural populations (e.g. White, 1961; Jacobs, 1977) they are probably transient and have little or no evolutionary importance. There are, however, a number of welldocumented examples of species in which structurally variant chromosomes occur at a high frequency in natural populations. A few of these chromosomal polymorphisms are known to be maintained by natural

\footnotetext{
*Present address: Hilbre, Bryn Gofal, Llangristiolus, Anglesey, Gwynedd LL62 5PR, Wales.

†To whom correspondence and reprint requests should be directed.
}

selection, e.g. the paracentric inversion sequences in Drosophila (reviewed by Williamson, 1972; Wallace, 1981), but other factors such as meiotic drive (e.g. Wilby \& Parker, 1988; Parker et al., 1988), a high level of asexual reproduction (e.g. Brandham \& Johnson, 1977 ), or a rapid mutation rate (e.g. Wilby \& Parker, 1987) may contribute towards the spread of chromosomal variants. In some species, structural heterozygotes appear to have an advantage in ecologically marginal populations, which are often subject to inbreeding (Lewis \& John, 1957; James, 1965; Wedberg et al., 1968; Bloom, 1977; see also Charlesworth et al., 1977).

Allium schoenoprasum L. (Liliaceae) is a bulbous, perennial plant which reproduces both vegetatively by the production of daughter bulbs on short rhizomes and sexually by the production of seed. In Britain, the species is uncommon and most of its disjunct popula- 
tions are comparatively small and occur in open, rocky habitats often on thin soils. Flowering and seed production are infrequent in some of these populations (Bougourd, 1977; Stevens, 1985). By contrast, in the Alps and Pyrenees in continental Europe, A. schoenoprasum is more abundant, and typically occurs in densely vegetated valley mires and water meadows. Flowering is prolific in these localities. It appears, therefore, that British populations of A. schoenoprasum are somewhat more ecologically marginal than their continental counterparts. Preliminary cytogenetic studies of British populations indicated that moderate levels of chromosome heterozygosity were present in at least two sites (Bougourd, 1977). In this paper we compare the incidence and meiotic behaviour of chromosome variants in populations of this species from Britain and continental Europe.

\section{Materials and methods}

\section{Sampling and cultivation}

In September 1981 and August 1982, mature bulbs of A. schoenoprasum were sampled at spaced intervals of at least $1 \mathrm{~m}$ from eight natural populations in Britain and 10 in continental Europe (Fig. 1). The plants were cultivated in Levington Universal compost in $8 \mathrm{~cm}$ diameter pots and maintained under controlled glasshouse conditions with supplementary lighting and heating to give a $16-\mathrm{h}$ day and to maintain a minimum temperature of $16^{\circ} \mathrm{C}$. The plants were transferred outside for 2-3 months during the winter to receive a cold chill which stimulates the production of flower buds.

\section{Cytological methods}

Meiosis was studied in pollen mother cells (PMCs), which were obtained from fresh or fixed (in 1:3 acetic-alcohol) flower buds and stained in 2 per cent lactopropionic orcein. Mitosis was studied in root tip cells, which were pretreated in 0.05 per cent colchicine for $2.5 \mathrm{~h}$, fixed in 1:3 acetic-alcohol, and stained by the Feulgen method.

Ten PMCs at first metaphase (M1) were examined per plant for multivalents, indicative of interchange heterozygosity, and asymmetrical bivalents, suggestive of deletion, supernumerary segment or pericentric inversion. One hundred PMCs at first anaphase (A1) were examined per plant for dicentric bridges with acentric fragments of constant size, suggestive of paracentric inversion heterozygosity. [Chiasmata are not localized in Allium schoenoprasum, so the fragments associated with dicentric bridges formed by U-type exchange are expected to be of unequal length (Jones, 1968).]

Karyotype analysis was carried out on suspected chromosomal heterozygotes, together with a more detailed analysis of their meiotic behaviour. The frequency of multivalent formation was scored for each interchange heterozygote, in a random sample of between 6 and 159 M1 PMCs, and the shape (ring or chain), orientation (alternate or adjacent), and presence or absence of interstitial chiasmata were noted for each multivalent. (The centromeres of the seven pairs of metacentric chromosomes in A. schoenoprasum are indistinguishable at M1, so the orientation of quadrivalents with interstitial chiasmata could not be determined.) To avoid bias, the meiotic behaviour of each interchange heterozygote was recorded only from slides where the interchange chromosomes could be identified in all M1 PMCs observed. For each paracentric inversion heterozygote the frequency of loops and dicentric bridges at $\mathrm{A} 1$ and the sizes of the associated acentric fragments, were scored in a random sample of 100-450 PMCs.

\section{Fertility testing}

The male and female fertilities of 16 different structural chromosome heterozygotes from six populations were estimated by scoring the percentage stainability of 250-300 pollen grains per plant in Alexander's Differential Stain (Alexander, 1969), and by counting seed set per capsule following manual cross-pollination of 12-20 flowers per plant with fertile pollen from a basic homozygote. The fertilities of each structural chromosome mutant were compared with the mean fertilities of 10-20 control plants (basic homozygotes) from the same population using a modified $t$-test (Sokal \& Rohlf, 1981) following arcsin square root transformation of percentage pollen stainability data, and square root transformation of seed set data. The fertility tests of chromosome mutants and control plants were carried out simultaneously in a uniform environment.

\section{Results}

\section{The basic karyotype}

Allium schoenoprasum is normally diploid with eight pairs of chromosomes that range in size from 5.6 to 8.3 $\mu \mathrm{m}$ at colchicine-metaphase (Fig. 2a). Chromosome pairs $1-7$ are metacentric, while pair 8 is acrocentric and carries the nucleolar-organizer region (NOR). During normal male meiosis, the eight bivalents usually have a total of between 15 and 17 non-localized chiasmata (Fig. 2b). 


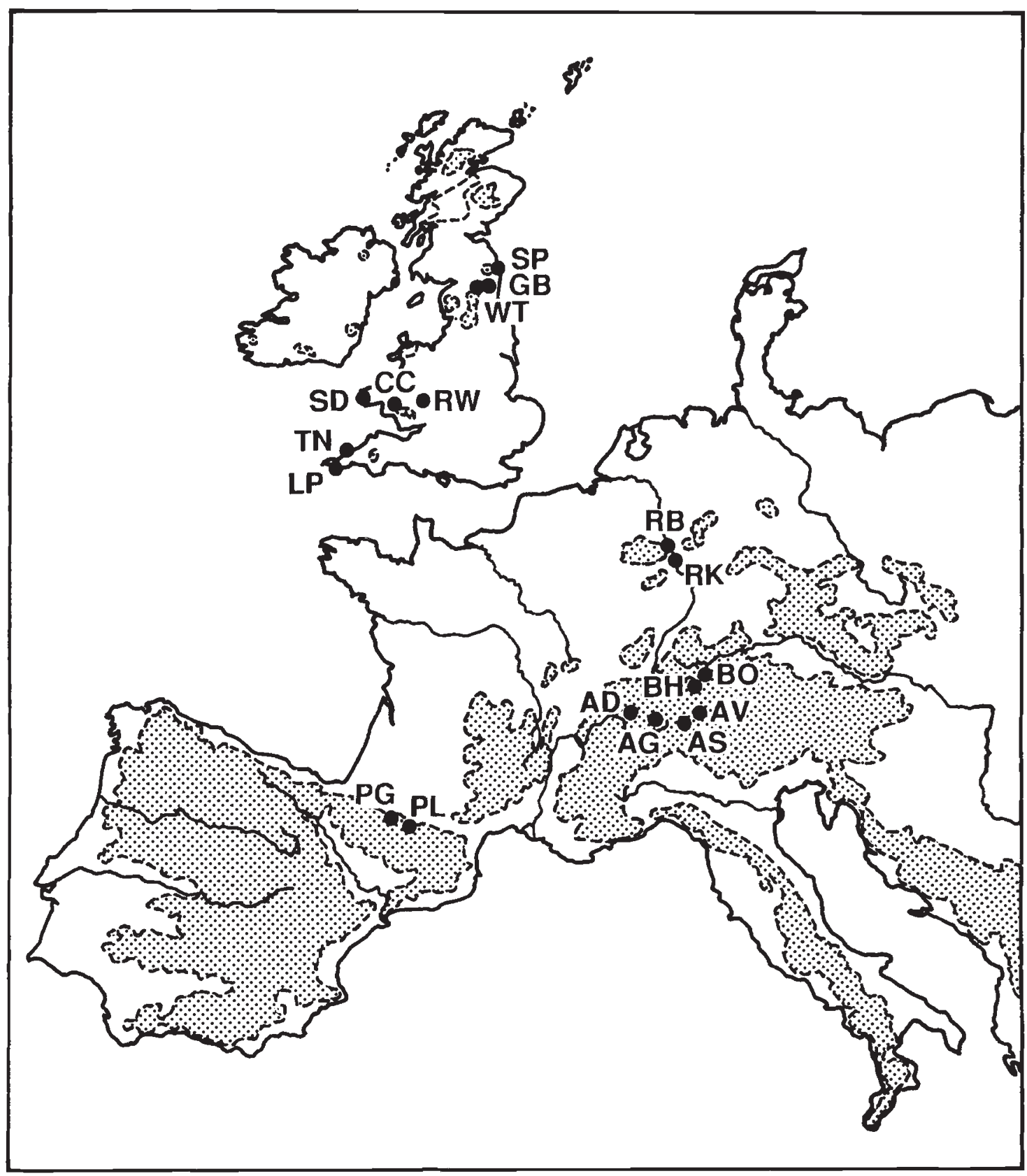

Fig. 1 Distribution of the 18 sampling sites of Allium schoenoprasum. Shaded areas =land over $500 \mathrm{~m}$.

Britain: SP = Spindlestone; GB = Great Bavington; WT = Walltown; RW= River Wye; CC $=$ Carreg Cennen; $\mathrm{SD}=\mathrm{St} \mathrm{David}$ 's

Head; $\mathrm{TN}=$ Tintagel; $\mathrm{LP}=$ Lizard Peninsula.

Rhine: $\mathrm{RB}=$ Brohl; $\mathrm{RK}=$ Krummenwerth.

Bodensee: $\mathrm{BO}=$ Oberxell; $\mathrm{BH}=$ Hegne.

Alps: $A D=$ Davos $A G=$ Gamchi; $A S=$ Sertig Dorfli; $A V=$ Vrin.

Pyrenees: $\mathrm{PG}=$ Gabas; $\mathrm{PL}=\mathrm{Lac}$ de Tracens.

\section{Numerical variants}

All but one of 1017 plants analysed meiotically were diploid. A single, highly sterile, triploid plant was found in the population sample of 144 plants from the Lizard Peninsula, England.
B-chromosomes were found in 22 per cent of plants from the River Wye, Wales, and in both populations from the French Pyrenees at frequencies of 11 per cent at the Gabas site and 74 per cent at the Lac de Tracens site (Stevens, 1985). The morphology and behaviour of the B-chromosomes are discussed elsewhere (Bou- 


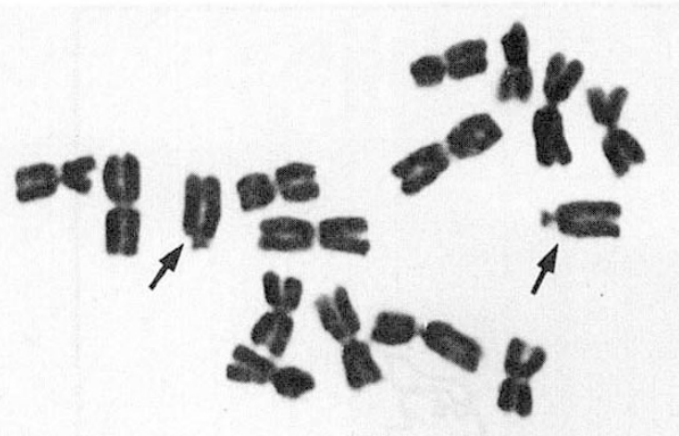

(a)

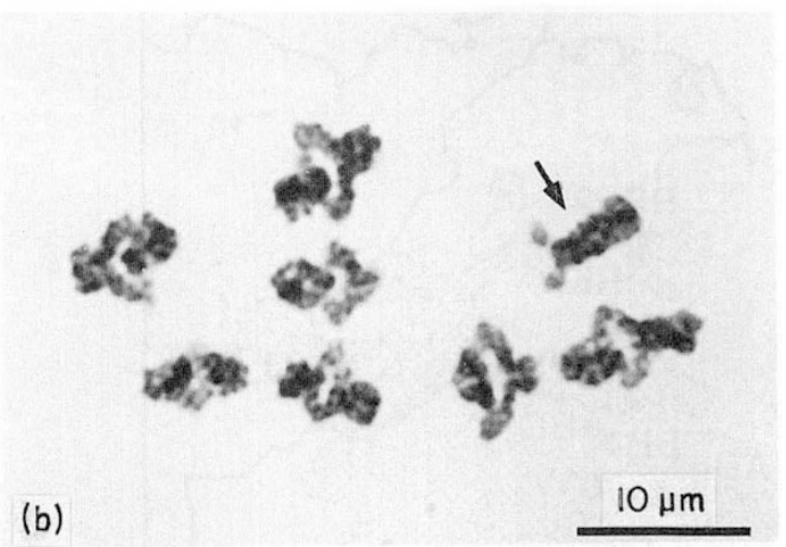

Fig. 2 Standard chromosome complement of Allium schoenoprasum: (a) colchicine-metaphase, (b) metaphase 1 of male meiosis (arrows indicate acrocentric chromosome pair).

gourd \& Parker, 1975, 1979a,b; Stevens, 1985; Holmes \& Bougourd, 1989).

\section{Structural mutants}

A total of 35 structural chromosome heterozygotes was found, two of which were heterozygous for two different chromosomal rearrangements (Table 1). No novel structural chromosome homozygotes were found, although homozygotes for symmetrical rearrangements would rarely have been detectable. The frequency of plants carrying one or more chromosomal rearrangements was slightly higher in the British than in the continental European population samples (3.8 and 2.8 per cent respectively), but this difference is not statistically significant $\left(\chi_{(1)}^{2}=0.43, P>0.5\right)$.

The 37 rearrangements identified comprise 23 interchanges, 12 paracentric inversions, one deletion and one supernumerary chromosome segment (Table 1).

Interchanges. Meiotic and karyotypic analyses revealed that the 23 interchanges consisted of 19 different rearrangements. Four bulbs sampled from the
Walltown population, Northumberland, England, all carried the same rearrangement, as did two bulbs sampled from the population near Tintagel, Cornwall, England (Fig. 3a and b). It is likely that the local spreading of these two interchange types has occurred asexually rather than sexually because no interchange homozygotes were found and heterozygotes for both rearrangements had very low fertilities (see Table 3, interchanges 2-5 and 18-19).

Eight of the 19 different interchanges detected involved an acrocentric (pair 8) chromosome (e.g. Fig. $3 \mathrm{c})$; the remaining 11 involved two metacentrics from pairs 1-7. Therefore, eight of 'the 38 chromosome breaks (21.1 per cent) occurred in an acrocentric. If the distribution of chromosome breaks is random, and the expected frequency per chromosome is calculated on the basis of relative chromosome length at colchicinemetaphase, 10.7 per cent of the breaks would be expected to occur in an acrocentric. The observed frequency (21.1 per cent) is significantly greater than this $\left(\chi_{(1)}^{2}=4.26, P<0.05\right)$, which suggests that chromosome breaks that result in viable gametes are distributed non-randomly in $A$. schoenoprasum.

Detailed analysis of M1 was possible for 15 different interchange types (suitable slides, with no unclassifiable PMCs, were unavailable for the remaining four). The results are summarized in Table 2 and examples shown in Fig. 4. On average, quadrivalent formation occurred in 68 per cent PMCs, but the range (from 13 to 95 per cent) was wide. Eight of the 15 different interchanges analysed involved an acrocentric chromosome, and interstitial chiasmata were especially common in four of these, occurring in over 60 per cent of multivalents (interchanges $1,2-5,7,21$ ). A similar level of chiasma formation in the interstitial segments occurred in only one of the seven interchange types that involved two metacentrics (interchange 18-19). The presence of an interstitial chiasma reduces the maximum number of genetically balanced meiotic products from four to two.

When chiasmata were restricted to the pairing segments, none of the eight interchanges that involved an acrocentric chromosome formed ring quadrivalents, whereas six of the seven that involved two metacentrics formed both ring and chain multiples. This reflects the virtual absence of crossing over in the short arms of the acrocentric chromosomes in A. schoenoprasum.

Alternate and adjacent orientations of ring quadrivalents were observed in approximately equal frequencies in all six heterozygotes that formed at least occasional ring multiples (Table 2). This is expected if the four centromeres of a quadrivalent orientate in pairs at random (John \& Lewis, 1965). By contrast, there was significant heterogeneity between interchange types in the orientation behaviour of chain 
Table 1 Frequency and classification of meiotically detectable structural chromosome heterozygotes in natural populations of Allium schoenoprasum from Britain and continental Europe

\begin{tabular}{|c|c|c|c|c|c|c|}
\hline \multirow[b]{2}{*}{ Population } & \multirow{2}{*}{$\begin{array}{l}\text { Total } \\
\text { plants }\end{array}$} & \multirow{2}{*}{$\begin{array}{l}\text { Number }(\%) \text { of } \\
\text { heterozygotes }\end{array}$} & \multicolumn{4}{|c|}{ Types of mutation } \\
\hline & & & Int. & Inv. & Del. & SS \\
\hline \multicolumn{7}{|l|}{ Britain } \\
\hline Great Bavington & 11 & $0(0.0)$ & - & - & - & - \\
\hline Spindlestone & 25 & $1(4.0)$ & 1 & - & - & - \\
\hline Walltown & 61 & $5(8.2)$ & 4 & - & 1 & - \\
\hline River Wye & 175 & $4(2.3)$ & 1 & 2 & - & 1 \\
\hline Carreg Cennen & 63 & $0(0.0)$ & - & - & - & - \\
\hline St David's Head & 72 & $4 *(5.6)$ & 3 & 3 & - & - \\
\hline Lizard Peninsula & 144 & $6(4.2)$ & 6 & - & - & - \\
\hline Tintagel & 78 & $4(5.2)$ & 4 & - & - & - \\
\hline Subtotal & 629 & $24(3.8)$ & 19 & 5 & 1 & 1 \\
\hline \multicolumn{7}{|l|}{ Continental Europe } \\
\hline Gabas & 27 & $1(3.7)$ & - & 1 & - & - \\
\hline Lac de Tracens & 20 & $0(0.0)$ & - & - & - & - \\
\hline Davos & 23 & $0(0.0)$ & - & - & - & - \\
\hline Sertig Dorfli & 24 & $0(0.0)$ & - & - & - & - \\
\hline Gamchi & 34 & $0(0.0)$ & - & - & - & - \\
\hline Vrin & 37 & $2(5.4)$ & 1 & 1 & - & - \\
\hline Oberxell & 44 & $1(2.3)$ & 1 & - & - & - \\
\hline Hegne & 59 & $1(1.7)$ & 1 & - & - & - \\
\hline Krummenwerth & 53 & $4(7.5)$ & - & 4 & - & - \\
\hline Brohl & 67 & $2(3.0)$ & 1 & 1 & - & - \\
\hline Subtotal & 388 & $11(2.8)$ & 4 & 7 & 0 & 0 \\
\hline Grand total & 1017 & $35(3.4)$ & 23 & 12 & 1 & 1 \\
\hline
\end{tabular}

*Two plants from St David's Head each carried two different chromosomal mutations.

Int. $=$ interchange, Inv. $=$ inversion, Del.$=$ deletion, $S S=$ supernumerary chromosome segment.

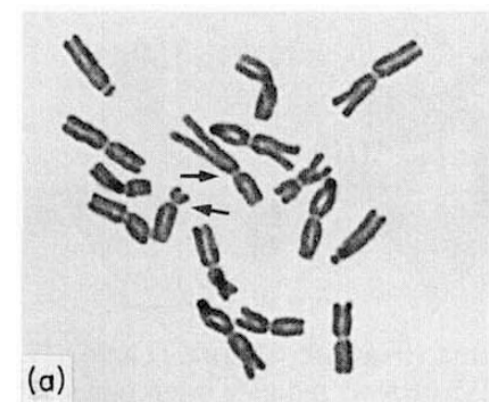

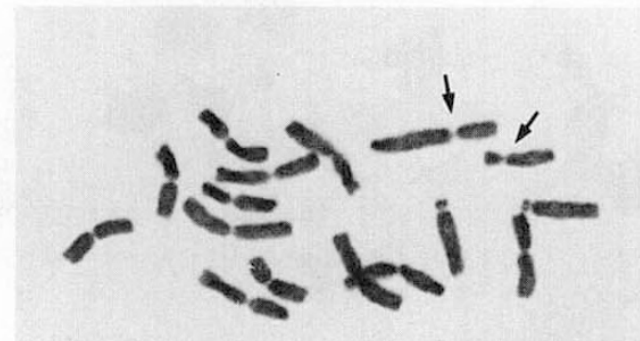

(b)

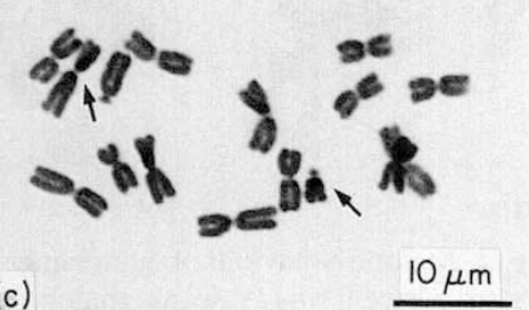

(c)

$10 \mu \mathrm{m}$

Fig. 3 Chromosome complements of interchange heterozygotes: (a) interchange 18, (b) interchange 19, (c) interchange 14 (arrows indicate interchange chromosomes).

quadrivalents (heterogeneity $\chi_{(4)}^{2}=20.13, P<0.001$, omitting data from interchanges with sample sizes of less than 10 chains). Chain quadrivalents tended to orientate alternately in interchanges 10,14 and 20 , whereas in interchange 18-19, adjacent orientation was more frequent (Table 2).
All the interchange heterozygotes detected were healthy, morphologically normal plants. However, the majority of those for which controlled fertility estimates were obtained had significantly reduced fecundities, with levels of pollen stainability ranging from 62 to 90 per cent of normal, and levels of seed set as low as 
Table 2 Meiotic behaviour of interchange heterozygotes scored at metaphase 1 (M1)

\begin{tabular}{|c|c|c|c|c|c|c|c|c|c|c|c|c|c|}
\hline \multirow{4}{*}{$\begin{array}{l}\text { Interchange } \\
\text { number }\end{array}$} & \multirow[b]{4}{*}{ Population } & \multirow{4}{*}{$\begin{array}{l}\text { Chromosome } \\
\text { pairs involved }\end{array}$} & \multirow{4}{*}{$\begin{array}{l}\text { Total } \\
\text { M1 } \\
\text { scored }\end{array}$} & \multirow{4}{*}{$\begin{array}{l}\text { Number } \\
(\%) \text { M1 } \\
\text { with IV }\end{array}$} & \multicolumn{9}{|c|}{ Meiotic configurations } \\
\hline & & & & & \multirow[b]{3}{*}{$8 \mathrm{II}$} & \multicolumn{5}{|c|}{ Xmata in pairing segments } & \multirow{2}{*}{\multicolumn{3}{|c|}{ Interstitial Xmata }} \\
\hline & & & & & & \multirow[b]{2}{*}{ III + I } & \multicolumn{2}{|c|}{ Ring IV } & \multicolumn{2}{|c|}{ Chain IV } & & & \\
\hline & & & & & & & alt. & adj. & alt. & adj. & $\mathrm{III}+\mathrm{I}$ & $\begin{array}{l}\text { Ring } \\
\text { IV }\end{array}$ & $\begin{array}{l}\text { Chain } \\
\text { IV }\end{array}$ \\
\hline 1 & Spindlestone & ac. mc. & 12 & $3(25)$ & 8 & - & - & - & - & - & 1 & - & 3 \\
\hline $2-5$ & Walltown & ac. mc. & 159 & $20(13)$ & 137 & - & - & - & - & - & 2 & - & 20 \\
\hline 6 & River Wye & mc. mc. & 23 & $17(74)$ & 6 & - & 6 & 8 & 2 & - & - & 1 & - \\
\hline 7 & St David's Head & ac. mc. & 13 & $11(85)$ & 2 & - & - & - & 2 & 1 & - & 8 & - \\
\hline 10 & Lizard Peninsula & mc. mc. & 21 & $20(95)$ & 1 & - & 5 & 4 & 9 & 2 & - & - & - \\
\hline 12 & Lizard Peninsula & ac. mc. & 62 & $19(31)$ & 43 & - & - & - & 8 & 11 & - & - & - \\
\hline 13 & Lizard Peninsula & mc. mc. & 55 & $49(89)$ & 6 & - & 20 & 21 & 4 & 4 & - & - & - \\
\hline 14 & Lizard Peninsula & ac. mc. & 27 & $21(78)$ & 6 & - & - & - & 15 & 6 & - & - & - \\
\hline 15 & Lizard Peninsula & mc. mc. & 30 & $21(70)$ & 9 & - & 8 & 8 & 3 & 1 & - & - & 1 \\
\hline 17 & Tintagel & mc. mc. & 35 & $34(94)$ & 2 & - & 10 & 13 & 4 & 5 & - & 1 & - \\
\hline $18-19$ & Tintagel & mc. mc. & 78 & $73(94)$ & 5 & - & - & - & 9 & 17 & - & - & 47 \\
\hline 20 & Vrin & ac. mc. & 57 & $51(89)$ & 6 & - & - & - & 40 & 11 & - & - & - \\
\hline 21 & Oberxell & ac. mc. & 6 & $5(83)$ & 1 & - & - & - & 1 & 1 & - & - & 3 \\
\hline 22 & Hegne & mc. mc. & 11 & $6(55)$ & 5 & - & 2 & 2 & 1 & 1 & - & - & - \\
\hline 23 & Brohl & ac. mc. & 7 & $3(43)$ & 1 & 3 & - & - & 3 & - & - & - & - \\
\hline
\end{tabular}

Xmata = chiasmata, $\mathrm{I}=$ univalent, $\mathrm{II}=$ bivalent, $\mathrm{III}=$ trivalent, $\mathrm{IV}=$ quadrivalent, alt. = alternative orientation, adj. $=$ adjacent .orientation, ac. $=$ acrocentric, mc. $=$ metacentric.

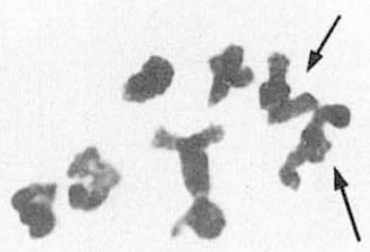

(a)

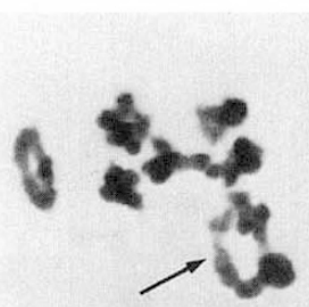

(d)

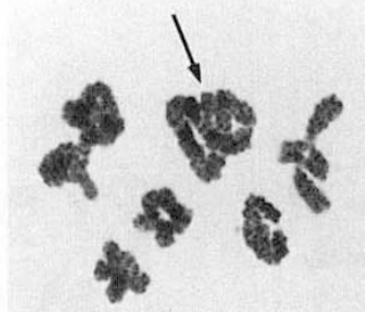

(e)

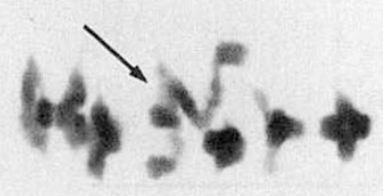

(b)

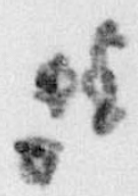

(c)

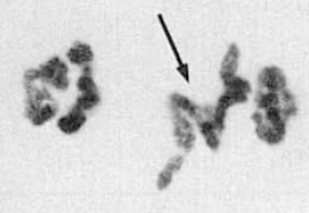

Fig. 4 Meiotic behaviour of interchange heterozygotes at metaphase 1: (a) asymmetrical bivalents, (b) and (c) alternate chain IVs, (d) adjacent ring IV, (e) alternate ring IV, ( $f$ ) and $(\mathrm{g}$ ) interstitial chiasmata in chain and ring IVs (arrows indicate interchange chromosome associations).

39 per cent of normal (Table 3 ). It should be noted that the female, and to a lesser extent male, fecundities of normal chromosomal homozygotes from the three populations in Northumberland, England (Great Bavington, Spindlestone and Walltown) are extremely low (for unknown reasons). Thus the fertility levels of some chromosomal heterozygotes from these sites, although low, are not significantly lower than those of the population controls.

\section{Inversions}

When crossing-over occurs in a reverse pairing loop in a paracentric inversion heterozygote, the length of the 
Table 3 Pollen and ovule fertilities of chromosome heterozygotes. For each heterozygote, stainability of 250-300 pollen grains, and seed set in 12-20 capsules, were scored. Each observation was compared with the mean of 10-20 control plants from the same population using a modified $t$-test (Sokal \& Rohlf, 1981). Population codes are given in Fig. 1

\begin{tabular}{|c|c|c|c|c|c|c|c|c|c|}
\hline \multirow[b]{2}{*}{ Mutant } & \multirow[b]{2}{*}{ Population } & \multicolumn{4}{|l|}{ Pollen fertility } & \multicolumn{4}{|c|}{ Ovule fertility } \\
\hline & & $\begin{array}{l}\text { Percentage of } \\
\text { pollen } \\
\text { stainability }\end{array}$ & $\begin{array}{l}\text { As percentage } \\
\text { of controls }\end{array}$ & $t$ & d.f. & $\begin{array}{l}\text { Seed set } \\
\text { per capsule }\end{array}$ & $\begin{array}{l}\text { As percentage } \\
\text { of controls }\end{array}$ & $t$ & d.f. \\
\hline \multicolumn{10}{|l|}{ Interchange } \\
\hline 1 & SP & 68.5 & 73.1 & $-3.572^{* *}$ & 18 & 0.4 & 117.6 & 0.337 & 9 \\
\hline $2-5$ & WT & 41.8 & 72.8 & -0.866 & 19 & 0.0 & - & -0.714 & 9 \\
\hline 8 & SD & 74.0 & 80.9 & $-3.590^{* *}$ & 13 & 2.5 & 65.4 & $-2.758^{*}$ & 13 \\
\hline 9 & SD & 65.9 & 72.1 & $-4.748^{* * *}$ & 13 & 2.3 & 60.2 & $-3.229^{* *}$ & 13 \\
\hline 11 & LP & 78.8 & 90.3 & $-2.134^{*}$ & 19 & 3.1 & 87.6 & -0.264 & 18 \\
\hline 12 & LP & 61.3 & 70.3 & $-4.339^{* * * *}$ & 19 & 2.5 & 70.6 & -1.006 & 18 \\
\hline 13 & LP & 76.2 & 87.4 & $-2.490^{*}$ & 19 & 1.4 & 39.4 & $-2.530^{*}$ & 18 \\
\hline 16 & TT & 62.0 & 71.4 & $-3.760^{* *}$ & 14 & - & - & & \\
\hline 17 & TT & 76.3 & 87.9 & -2.120 & 14 & 2.9 & 83.8 & -0.883 & 14 \\
\hline $18-19$ & TT & 53.6 & 61.8 & $-4.662^{* *}$ & 14 & 1.6 & 46.2 & $-2.591^{*}$ & 14 \\
\hline \multicolumn{10}{|l|}{ Inversion } \\
\hline 1 & RW & 0.0 & - & $-15.533^{* * *}$ & 15 & 4.9 & 122.8 & 1.616 & 15 \\
\hline 2 & RW & 89.2 & 93.4 & -0.854 & 15 & 4.1 & 102.8 & 0.206 & 15 \\
\hline $3 / 4$ & SD & 79.4 & 86.6 & $-2.753^{*}$ & 13 & 4.2 & 109.9 & 0.662 & 13 \\
\hline Deletion & WT & 53.5 & 93.2 & -0.270 & 19 & 0.0 & - & -0.714 & 9 \\
\hline $\begin{array}{l}\text { Supernumeray } \\
\text { segment }\end{array}$ & RW & 93.0 & 97.4 & -0.058 & 15 & 4.4 & 110.3 & 0.745 & 15 \\
\hline
\end{tabular}

${ }^{*}=P<0.05$; $^{* *}=P<0.01 ; * *=P<0.001$.

acentric fragment associated with the resulting A1 dicentric bridge (or loop) is always constant, and equal to the length of the inverted segment plus twice the length of the distal segment. Slight variation of fragment lengths is, however, inevitable following squash preparations of meiosis due to differential stretching or folding of the fragments.

Data on the meiotic behaviour at A1 of plants carrying the 12 paracentric inversions are given in Table 4 and examples are shown in Fig. 5. The small number of fragments of a non-uniform length (e.g. $5.5 \mu \mathrm{m}$, inversion 1) are probably caused by U-type exchange. Abnormalities indicative of $U$-type exchange were observed in 33 per cent of 1017 plants studied, in an average of 1.67 per cent PMCs per affected plant (Stevens, 1985).

It is likely that inversions 9 and 10 from Krummenwerth, West Germany, are the same because both involve an acrocentric chromosome, and they have similar meiotic characteristics (Table 4).

In total, four (27 per cent) of the 11 different inversion types found involved an acrocentric chromosome. This is considerably more than the expected frequency of 10.7 per cent, although the expected number $(1)$ is too small for a statistical test of significance to be performed.

The products of reverse loop chiasmata occurred in a low proportion of PMCs in the 11 inversion types detected (mean $=6$ per cent PMCs, range $=3-13$ per cent PMCs). The fertilities of three inversion heterozygotes, including the plant carrying inversions 3 and 4 , were tested, and the results are given in Table 3 . Seed set was not reduced. However, the plant carrying inversions 3 and 4 had a significantly reduced pollen stainability, and the plant carrying inversion 1 was completely male sterile, but this was probably for reasons unconnected with the chromosomal rearrangement.

\section{Deficiency}

A single, phenotypically normal plant from the Walltown population, Northumberland, England, carried a deletion of the entire short arm of an acrocentric chromosome (Fig. 6). This arm constitutes 1.02 per cent of the haploid genome at colchicine-metaphase, it is at least partly heterochromatic, and it carries the NOR. A maximum of one rather than two nucleoli 


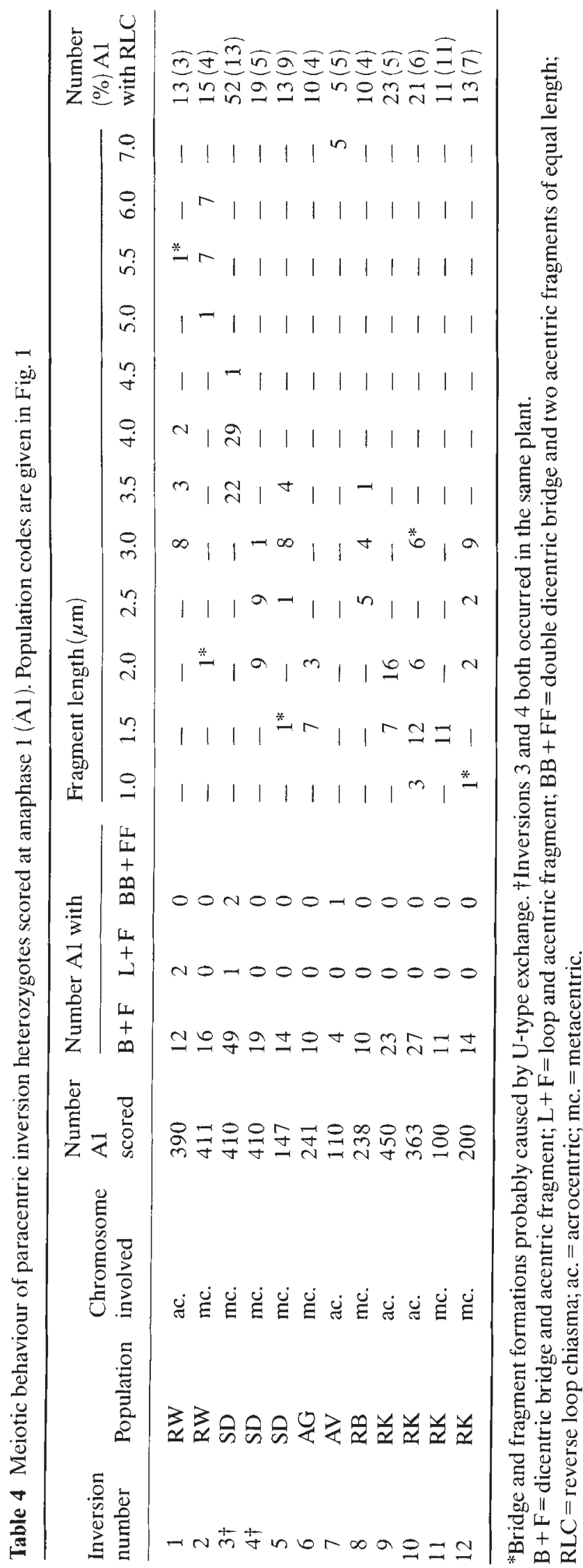

occurred in root tip cells. The pollen and ovule fertilities of the deletion heterozygote were not significantly below those of the control plants from Walltown (Table 3 ). Relatively large ( $>1.0$ per cent of the genome) viable deficiencies are known to occur in a number of other diploid plant and animal species (Finch, 1983) but this is believed to be the first report of such a mutation in A. schoenoprasum.

\section{Supernumerary chromosome segment}

A single plant from the River Wye population, Wales, was heterozygous for a mitotically stable supernumerary chromosome segment situated terminally on the short arm of an acrocentric chromosome distal to the NOR which was visible as a secondary constriction (Fig. 7a and b). The segment was approximately 1.24 $\mu \mathrm{m}$ long at colchicine-metaphase, causing a threefold increase in the length of the standard acrocentric short arm. Its presence did not appear to affect fertility (Table 3).

A probable chiasmate association was observed between the supernumerary chromosome segment and a metacentric bivalent in one M1 PMC (out of 80 examined) (Fig. 7c). This suggests that the segment may have arisen from a viable duplication-deficiency gamete produced by an interchange heterozygote carrying an unequal translocation involving the short arm of an acrocentric chromosome.

\section{Discussion}

In natural populations of $A$. schoenoprasum from Britain and continental Europe, 3.6 per cent of mature plants have been shown to be heterozygous for meiotically detectable structural chromosome rearrangements. This finding reinforces the conclusion reached by Parker et al. (1988) from cytological studies on Scilla autumnalis (Ainsworth et al., 1983; see also Guillén \& Ruiz Rejón, 1984) and Rumex acetosa (Wilby \& Parker, 1989) that the frequency of structural rearrangement in plants may be at least an order of magnitude higher than that of between 1 in 200 and 1 in 500 generally thought to be present in natural populations (White, 1973, 1978). High levels of karyotypic heterogeneity have also been reported in members of the Aloineae (Brandham, 1974, 1976). However, both in $A$. schoenoprasum and in the other species mentioned here, the variability is superimposed on a karyotype that appears to be fundamentally stable over a wide geographic range.

In A. schoenoprasum, there does not appear to have been selection for particular structural chromosome rearrangements in the populations studied. Moreover, 
Fig. 5 Meiotic behaviour of paracentric inversion heterozygotes at anaphase 1 : (a) bridge and fragment,

(b) loop (arrowed) and fragment,

(c) double bridge and two fragments.
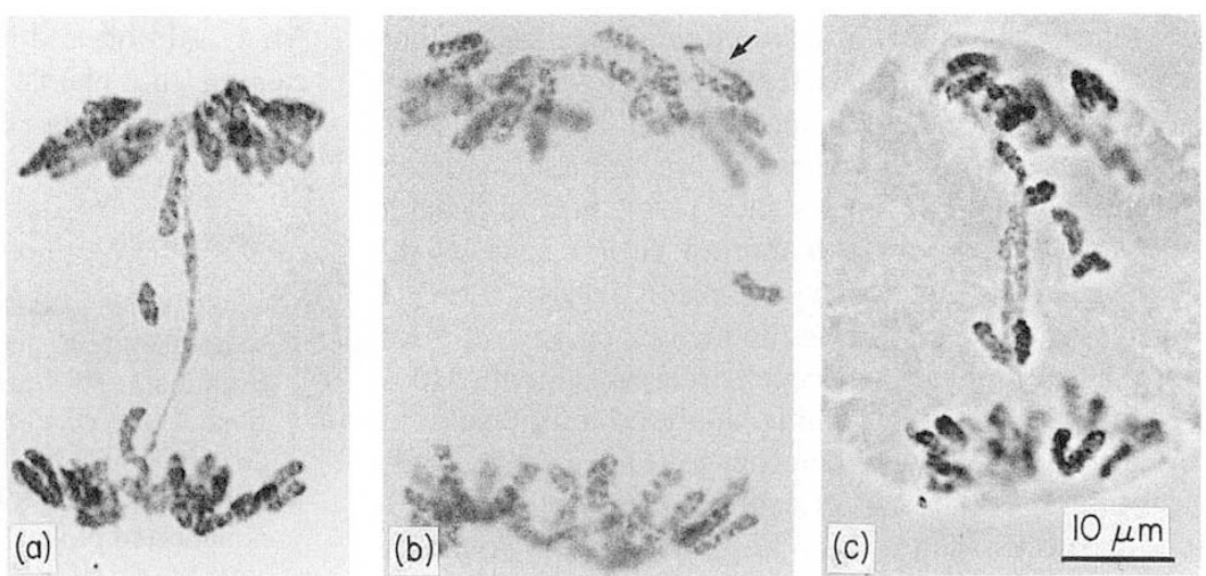

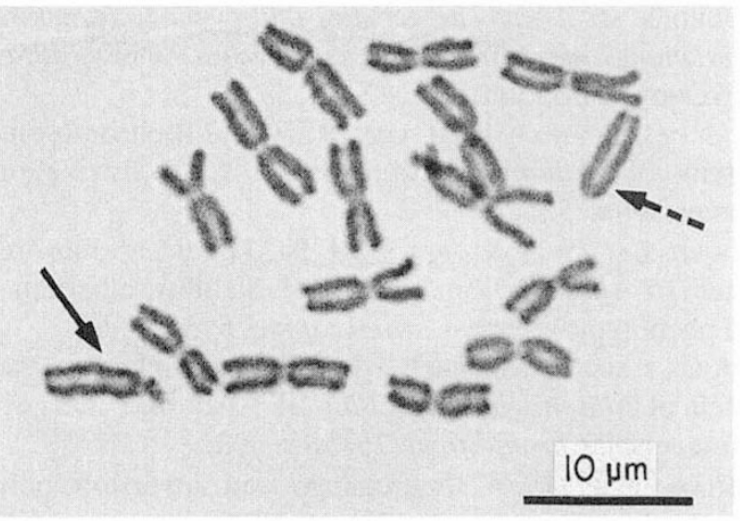

Fig. 6 Chromosome complement of deletion heterozygote (hatched arrow indicates deleted acrocentric and solid arrow indicates normal acrocentric).

there was no significant difference between the British and the continental European populations in the frequency of major structural rearrangements. The British populations are small and more ecologically marginal, and one might have expected them to be relatively inbred. Enforced inbreeding of a normally outbreeding species could result in an increased rate of spontaneous breakage (e.g. Rees, 1961a) or it could lead to enhanced selection pressure for chromosomal mechanisms that help conserve co-adapted gene complexes (e.g. Rees, 1961b). However, our recent work on inbreeding depression in $A$. schoenoprasum suggests that the British populations are no more inbred than the continental ones (Stevens \& Bougourd, 1988). In addition, the relatively high frequency of non-localized chiasmata that are characteristic of meiosis in this species may render it somewhat unsuitable for the establishment of interchange and inversion polymorphism.

Significantly more structural chromosome variants involved the acrocentric nucleolar-organizer chromosome pair than would have been expected on the basis of relative chromosome lengths at colchicine-metaphase. Data from the preliminary cytological investigation of $A$. schoenoprasum suggest a similar nonrandom distribution of breakpoints (Bougourd, 1977). Apparently non-random distributions of inversions (e.g. Dobzhansky \& Sturtevant, 1938) and interchanges (e.g. Savage \& Bigger, 1976) have been observed in other organisms. It is possible that the acrocentric chromosomes of $A$. schoenoprasum are particularly prone to breakage, or alternatively that a higher proportion of structural mutations involving the acrocentrics is viable.
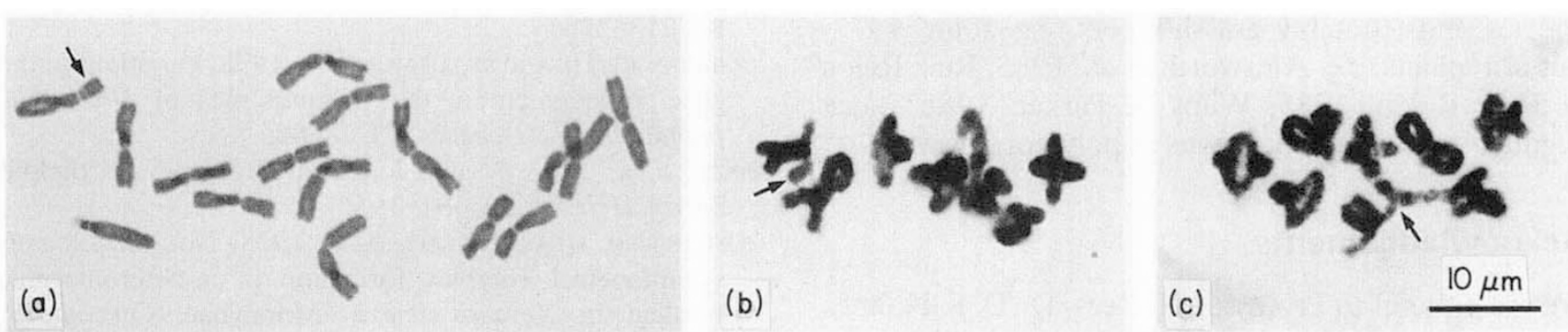

Fig. 7 Chromosome complement and meiotic behaviour at M1 of supernumerary chromosome segment heterozygote: (a) colchicine-metaphase, (b) 8 bivalents, (c) 6 bivalents plus probable IV (arrows indicate supernumerary chromosome segment). 
Meiotic analysis is a more effective technique than mitotic analysis for the detection of paracentric inversion and interchange heterozygotes. However, pericentric inversion heterozygotes are difficult to detect by either technique unless they result in a noticeable shift in the position of a marker region such as the centromere or nucleolar-organizer region. The 12 inversions detected during the meiotic survey reported here did not include pericentric rearrangements. However, three of 1239 plants analysed mitotically by Bougourd (1977) were heterozygous for a centric shift, presumably caused by pericentric inversion.

The successful detection of paracentric inversions at first anaphase depends upon the formation of reverse pairing loops in which crossing-over occurs during pachytene. Although reverse loops have been observed in a few species (e.g. Watanabe \& Noda, 1974) and the products of reverse loop chiasmata have been observed in many more (e.g. Brandham, 1977), reverse loop pairing is not universal. Instead straight, nonhomologous pairing may occur across mutually inverted segments (Fletcher \& Hewitt, 1978), or the segments may remain unsynapsed. Paracentric inversions that never, or only rarely, form reverse loop chiasmata will not have been detected during the present study.

A supernumerary chromosome segment has previously been reported in $A$. schoenoprasum (Bougourd, 1977). However, this segment was mitotically unstable. It occurred in about 60 per cent of root tip cells of a single individual amongst the progeny of a cross between one plant from the River Wye, Wales, and one from the Lizard Peninsula, England; neither parent carried the extra segment. This segment, like the segment described here, was also attached to the short arm of an acrocentric chromosome; it resembled an enlarged satellite region and varied in length from 1.3 to $5.4 \mu \mathrm{m}$ at colchicine-metaphase. Unstable segments, resembling enlarged satellites, have been reported in other species (Marchant \& Brighton, 1971; Brandham, 1975). The supernumerary segment reported here is believed to be the first report of a stable supernumerary segment in $A$. schoenoprasum. In some species, most notably grasshoppers (e.g. John, 1973) but also plants (e.g. Ainsworth et al., 1983; Ruiz Rejón \& Ruiz Rejón, 1985; Wilby \& Parker, 1988), such segments occur in populations as polymorphisms.

\section{Acknowledgements}

We are grateful to Professor H. Rees, Dr D. S. Holmes and $\mathrm{Mr} \mathrm{J}$. Evans for their valuable discussion, to $\mathrm{Dr}$ D. P. Stevens for assistance with the population sampling and for critical comments on the manuscript, and to
Mr C. Abbott and Mr K. Partridge for help with maintaining the plants. JPS gratefully acknowledges the financial assistance of the SERC.

\section{References}

AINSWORTH, C. C., PARKER, J. S. AND horTon, D. M. 1983. Chromosome variation and evolution in Scilla autumnalis. In: Brandham, P. E. and Bennett, M. D. (eds) Kew Chromosome Conference II. George Allen \& Unwin, London, pp. 261-268.

ALEXANDER, M. P. 1969. Differential staining of aborted and nonaborted pollen. Stain Technol., 44, 117-122.

BLOOM, w. L. 1977. Translocation heterozygosity, genetic heterozygosity and inbreeding in Clarkia speciosa. Evolution, 31, 256-264.

Bougourd, s. M. 1977. The genetics and cytology of natural populations of Allium schoenoprasum. PhD thesis, University of London.

BOUGOURD, S. M. AND PARKER, J. S. 1975. The B-chromosome system of Allium schoenoprasum. I. B-distribution. Chromosoma, 53, 273-282.

BOUGOURD, S. M. AND PARKER, J. S. 1979a. The B-chromosome system of Allium schoenoprasum. II. Stability, inheritance and phenotypic effects. Chromosoma, 75, 369-383.

BOUGOURD, S. M. AND PARKER, J. S. 1979b. The B-chromosome system of Allium schoenoprasum. III. An abrupt change in B-frequency. Chromosoma, 75, 385-392.

BRANDHAM, P. E. 1974. Interchange and inversion polymorphism among populations of Haworthia reinwardtii var chalumnensis. Chromosoma, 47, 85-108.

BRANDHAM, P. E. 1975. Stabilised breakage of a duplicated chromosome segment in Aloe. Chromosoma, 51, 269-278.

BRANDHAM, P. E. 1976. The frequency of spontaneous structural change. In: Jones, K. E. and Brandham, P. E. (eds) Current Chromosome Research, Elsevier, Amsterdam, pp. 77-87.

BRANDHAM, P. E. 1977. The meiotic behaviour of inversions in polyploid Aloineae. I. Paracentric inversions. Chromosoma, 62, 69-84.

BRANDham, P. E. AND JOHNSON, M. A. T. 1977. Population cytology of structural and numerical chromosome variants in the Aloineae (Liliaceae). Pl. Syst. Evol, 128, 105-122.

CHARLESWORTH, D., CHARLESWORTH, B. AND STROBECK, C. 1977. Effects of selfing on selection for recombination. Genetics, 86, 213-226.

DOBZHANSKY, TH. AND STURTEVANT, A. H. 1938. Variations in the gene arrangement in the chromosomes of Drosophila pseudoobscura. Genetics, 23, 28-64.

FINCH, R. A. 1983. Viable long-arm deficiency in diploid barley. Heredity, 50, 191-195.

FLETCHER, H. L. AND HEWIT, G. M. 1978. Non-homologous synaptonemal complex formation in a heteromorphic bivalent in Keyacris scurra (Morabinae, Orthoptera). Chromosoma, 65, 271-281.

GUILLÉN, A. AND RUIZ REJON, M. 1984. Structural variability and chromosome number variation in natural populations of 
Scilla autumnalis (Liliaceae). Pl. Syst. Evol., 144, 201-207.

HOLMES, D. S. AND BOUGOURD, S. M. 1989. B-chromosome selection in Allium schoenoprasum. I. Natural populations. Heredity, 63, 83-87.

JACOBS, P. A. 1977. Structural rearrangements of the chromosomes in man. In: Hook, E. B. and Porter, I. H. (eds) Population Cytogenetics. Studies in Humans. Academic Press, London.

JAMES, S. H. 1965. Complex hybridity in Isotoma petrea. I. The occurrence of interchange heterozygosity, autogamy and a balanced lethal system. Heredity, 20,341-353.

JoHN, B. 1973. The cytogenetic systems of grasshoppers and locusts. II. The origin and evolution of supernumerary segments. Chromosoma, 44, 123-146.

John, B. AND Lewis, K. R. 1965. The Meiotic System. Protoplasmatologia VI. Springer-Verlag, Vienna.

JONES, G. H. 1968. Meiotic errors in rye related to chiasma formation. Mut. Res., 5, 385-395.

LEWIS, K. R. AND JoHN, B. 1957. Studies on Periplaneta americana. II. Interchange heterozygosity in isolated populations. Heredity, 11, 11-22.

MARCHANT, C. J. AND BRIGHTON, C. A. 1971. Mitotic instability in the short arm of a heteromorphic SAT-chromosome of tetraploid Ranunculus ficaria L. Chromosoma, 34, 1-18.

PARKER, J. S., WILBY, A. S. AND TAYLOR, s. 1988. Chromosome stability and instability in plants. In: Brandham, P. E. (ed.) Kew Chromosome Conference III, HMSO, London, pp. 131-140.

REES, H. 1961a. Genotypic control of chromosome form and behaviour. Bot. Rev., 27, 288-318.

REES, H. 1961b. The consequences of interchange. Evolution, 15, 145-152.

RUIZ REJON, C. AND RUIZ REJON, M. 1985. Chromosomal polymorphism for a heterochromatic supernumerary segment in a natural population of Tulipa australis Link. (Liliaceae). Can.J. Genet. Cytol., 27, 633-638.

SAVAGE, J. R. K. AND BIGGER, T. R. L. 1976. Location of induced chromosomal aberrations in relation to ASG bands. In: Jones, K. and Brandham, P. E. (eds) Current Chromosome Research, Elsevier, Amsterdam, pp. 97-103.

SOKAL, R. R. AND ROHLF, F. J. 1981. Biometry. 2nd ed. W. H. Freeman \& Co., San Francisco.

STEVENS, J. P. 1985. The meiotic and breeding systems of Allium schoenoprasum in natural populations. D. Phil. Thesis, University of York.

STEVENS, J. P. AND BOUGOURD, S. M. 1988. Inbreeding depression and the outcrossing rate in natural populations of Allium schoenoprasum L. Heredity, 60, 257-261.

wallace, B. 1981. Basic Population Genetics. Columbia University Press, New York.

WATANABE, H. AND NODA, s. 1974. Chiasma studies in structural hybrids. XI. Pericentric inversion in Allium thunbergii. Nucleus, 17, 114-117.

WEDBERG, H. L., LEWIS, H. AND VENKATESH, C. H. 1968. Translocation heterozygotes and supernumerary chromosomes in wild populations of Clarkia williamsonii. Evolution, 22, 93-107.

WHite, M. J. D. 1961. Cytogenetics of the grasshopper Moraba scurra VI. A spontaneous pericentric inversion. Aust. J. Zoology, 9, 784-790.

white, M. J. D. 1973. Animal Cytology and Evolution. Cambridge University Press, Cambridge.

WHITE, M. J. D. 1978. Modes of Speciation. W. J. Freeman, San Francisco.

WILBY, A. S. AND PARKER, J. s. 1987. Population structure of hypervariable Y-chromosomes in Rumex acetosa. Heredity, 59, 135-143.

WILBY, A. S. AND PARKER, J. s. 1988. The supernumerary segment systems of Rumex acetosa. Heredity, $\mathbf{6 0}$, 109-117.

WILBY, A. S. AND PARKER, J. S. 1989. Extreme chromosomal heterogeneity in a small-island population of Rumex acetosa. Heredity, 62, 133-140.

williamson, M. 1972. The Analysis of Biological Populations. Edward Arnold, London. 